\title{
A COMPARISON OF THE EFFECTS OF A.T. 10 (DIHYDROTACHY- STEROL) AND VITAMIN D ON CALCIUM AND PHOSPHORUS METABOLISM IN HYPOPARATHYROIDISM
}

\author{
By FULLER ALBRIGHT, ESTHER BLOOMBERG, TRUMAN DRAKE, AND \\ HIRSH W. SULKOWITCH \\ (From the Medical Service of the Massachusetts General Hospital and the Department of \\ Medicine of the Harvard University Medical School, Boston)
}

(Received for publication January 21, 1938)

Since the paper by Holtz in 1933 (1) there has appeared in the German literature a considerable number of articles on a photochemical derivative of ergosterin, designated dihydrotachysterol or A.T. 10 (antitetanisches Präparat Nr. 10). Until recently this substance has not been available in this country. One gets the impression from the German literature (see below) that A.T. 10 and vitamin $\mathrm{D}$ effect calcium metabolism in much the same way with the one extraordinary difference that A.T. 10 is not antirachitic. This combination of facts is most surprising since at first thought it is hard to believe that any substance, chemically so closely related to vitamin $\mathrm{D}$, could have so similar an action on calcium metabolism and still not cure rickets. It thus becomes of interest to know the exact manner in which this new substance effects calcium and phosphorous metabolism and wherein its action differs from that of vitamin D. No complete metabolic data have as yet appeared. Therefore the present investigations were undertaken. They consist of calcium and phosphorus metabolic studies on 3 cases of hypoparathyroidism treated with A.T. 10, two of whom were later treated with vitamin D for comparison. ${ }^{1}$ Patients with hypoparathyroidism were chosen for this study so that secondary changes in calcium and phosphorus metabolism resulting from varying degrees of activity of the patient's own parathyroid tissue would not be confused with changes due to the A.T. 10. The importance of this aspect was discussed in a paper concerned with the action of vitamin D (2).

\section{REVIEW OF LITERATURE}

Bamburger (3), von Wendt (4), and Windaus (5) were the first to suggest that the toxic effect and anti-

\footnotetext{
1 Part of the A.T. 10 and all of the vitamin D were supplied by Mr. C. B. Taft of the Winthrop Chemical Company. The preparation of vitamin D used was "Drisdol" which is a preparation of crystalline vitamin $\mathrm{D}_{2}$.
}

rachitic effect of irradiated ergosterin were owing to two different factors. The previous conception had been that the toxic manifestations-calcium deposits in various organs and hypercalcemia-were due to an overabundance of the antirachitic factor-hence, a hypervitaminosis. This toxic factor was called by Holtz et al. (6) the "Calcinosefaktor" to differentiate it from the antirachitic factor.

Holtz, Gissel, and Rossmann (7) studied the various derivatives of ergosterin. It was found $(7,8)$ that upon irradiation of ergosterin with ultraviolet light one obtained the following substances: ergosterin, lumisterin, tachysterin, vitamin D, toxisterin, suprasterin $I$, and suprasterin II. Of these, tachysterin, vitamin $D$, and toxisterin contained the "Calcinosefaktor"; vitamin D alone, contained the antirachitic factor. Holtz conceived the idea that the "Calcinosefaktor" might be made use of in treating the hypocalcemia of hypoparathyroidism. To this end tachysterin was converted chemically into dihydrotachysterol, A.T. 10, to render it suitable for peroral administration.

A method of standardizing the toxic effect of ergosterin derivatives has been worked out (7). The unit of toxicity is designated the "Toxische Grenzdosis" (T.G.) and is that amount which given to mice for 12 days will cause a weight loss of at least 12 per cent. It is therefore possible to compare the antirachitic and the toxic properties of various preparations. Harnapp gave the following figures (9):

1 cc. vigantol $2 \ldots 4,500$ antirachitic units 1 cc. A.T. $10 \ldots \ldots 400$ antirachitic units

1.5 T.G. 150.0 T.G.

Incidentally, this is the only reference which suggests that A.T. 10 is antirachitic at all.

Furthermore, since the parathyroid hormone if given in excess likewise causes death to animals due to hypercalcemia and metastatic calcification, it is possible to compare the effect of A.T. 10 with that of parathyroid extract. Thus it was found that a dose of 0.2 to 1.0 unit of parathormone per kilo, on thyroparathyroidectomized dogs, was required to maintain a normal blood calcium level, while it took 1.5 to 3.5 T.G. units of A.T. 10. Hence 1 unit of parathormone corresponds to about

2 Vigantol is the trade name for a preparation of irradiated ergosterol marketed by Merck of Darmstadt and by I. G. Farhenindustrie. One cc. vigantol now contains 12,000 International Vitamin D units. 
5 T.G. units dihydrotachysterol. According to a recent symposium (10) A.T. 10 has been further purified and its biological activity is now assayed on parathyroidectomized dogs.

Numerous papers state that A.T. 10 is not antirachitic and it seems that this fact must have been ascertained on animals. The protocols of such experiments have not been found. Harnapp (9), however, found that A.T. 10 had no effect in curing infantile rickets or in raising the serum calcium level in such cases. Bomskov (10), on the other hand, found that A.T. 10 therapy will raise the serum calcium level in spasmophilia, but agrees that it will not correct the underlying rickets. Eckert (10) found A.T. 10 effective in late rickets. Dr. Alfred Shohl at the Children's Hospital in Boston in some preliminary and as yet unpublished experiments found that A.T. 10 was not antirachitic in rats.

The literature leaves no doubt that A.T. 10 is very effective for the treatment of hypoparathyroidism (11 to 31 inclusive). Reschke as quoted by Rieder (17) stated in 1934 that 200 cases had been treated without a single failure. Holtz (19) cited one patient who had been taking A.T. 10 for 3 years without any ill effect. Another patient died of acute yellow atrophy after taking the drug for 2 years ( 340 cc. of A.T. 10 in all) and at autopsy showed no evidence of calcification of the kidneys. It has also been used with benefit in tetany due to sprue $(17,18)$.

The dosage varies with the individual. Holtz (19) states that 2 to $5 \mathrm{cc}$. of A.T. weekly should be sufficient in mild cases of tetany. When the serum calcium has reached a normal level, the dosage is reduced. Martini and Heymer (16) reported a case of postoperative tetany which required $10 \mathrm{cc}$. of A.T. 10 daily for about 2 weeks in order to obtain symptomatic relief. Many observers warn against the dangers of overdosage which are increased by the marked cumulative action of the drug. Arnold, Holtz, and Marx (32) found that 6 times as much A.T. 10 are required toward the end of pregnancy as otherwise. During periods of marked activity (8, 26 ), nervous strains, and menstruation a larger dosage is usually necessary. The requirement for A.T. 10 decreases in women, after x-ray castration (29). The cataracts, so commonly seen in conjunction with hypoparathyroidism, can be kept from developing, but are not influenced by the drug once they have formed (10, $18,19,33)$.

The drug has been used with apparently good results in conditions other than those associated with hypocalcemia. These include hemophilia $(17,18,34,35)$, impetigo herpetiformis (10), peripheral circulatory conditions (36), and a variety of other conditions. Kappis as quoted by Rieder (18) treated "coeliakie." Gissel (35) reported good results using A.T. 10 in the treatment of bronchial asthma as well as in drug and serum eruptions. Wendt and Altenburger (22) treated severe urticaria with the drug. Danckelman (37) in 1934 reported treating painful varices and phlebitic residuals with A.T. 10.

Very little data are available on the action of the drug on the body chemistry. All observers agree that the serum calcium level is raised. Holtz and Kramer (38) found that both fractions of calcium are elevated, the ionized and that bound to protein. In cases with tetany as opposed to normal controls the effect is more predominantly on the ionized fraction. With elevation in the serum calcium level there is an increase in the urinary calcium excretion (41) which may lead to stone formation (38). The fecal calcium excretion is decreased $(38,39)$. Jordans (30) and Holtz and Kramer (38), furthermore, found that if a low calcium diet is used, calcium will be mobilized from the skeleton. Hoff (40) in one case of hypoparathyroidism found a slight elevation in the serum phosphorus level after treatment followed by a later fall. Snapper (14) and Arnold and Blum (26) found a lowering of the serum phosphorus level following treatment. Otherwise no data have been found on the phosphorus metabolism. Halbertsma (27) mentioned a mobilization of calcium with an increase in the calcium level of the blood, but with no increase in the serum phosphorus level. Hoff (40) observed a slight rise in serum magnesium, no decided change in serum potassium, and a slight rise in the "alkali reserves" with A.T. 10 therapy. Holtz (10) could not confirm the changes in the alkali reserve.

Arnold, Holtz, and Marx (32) found the action of A.T. 10 antagonized by estrin and the male sex hormone.

\section{Experiment I}

The subject, W. C., Patient 3, Number 14,727, of the first investigation (2) was a 16 year old boy with severe idiopathic hypoparathyroidism. A detailed clinical history will appear elsewhere (42).

The experiment was divided into Parts $A$ and B. In Part A he received A.T. 10, in Part B he received crystalline vitamin D. Sufficient time was allowed to elapse between the two parts of the experiment so that his metabolic levels would return to the pretherapeutic values. Throughout the entire experiment he received a diet of an exactly similar composition each day. This consisted of a low calcium, moderately high phosphorus diet. In addition, 0.45 of a gram of calcium in the form of calcium gluconate was given daily by mouth in three divided doses. Thus, it was thought, sufficient calcium and phosphorus was being ingested to give the drug something to act upon if its action were on the absorption of calcium or phosphorus. The data are shown in Figure 1 and Table IA and Table IB.

During the three control periods (Periods 1, 2, and 3) there were present a low serum calcium level (7.0 mgm. per $100 \mathrm{cc}$.), a high serum phos- 


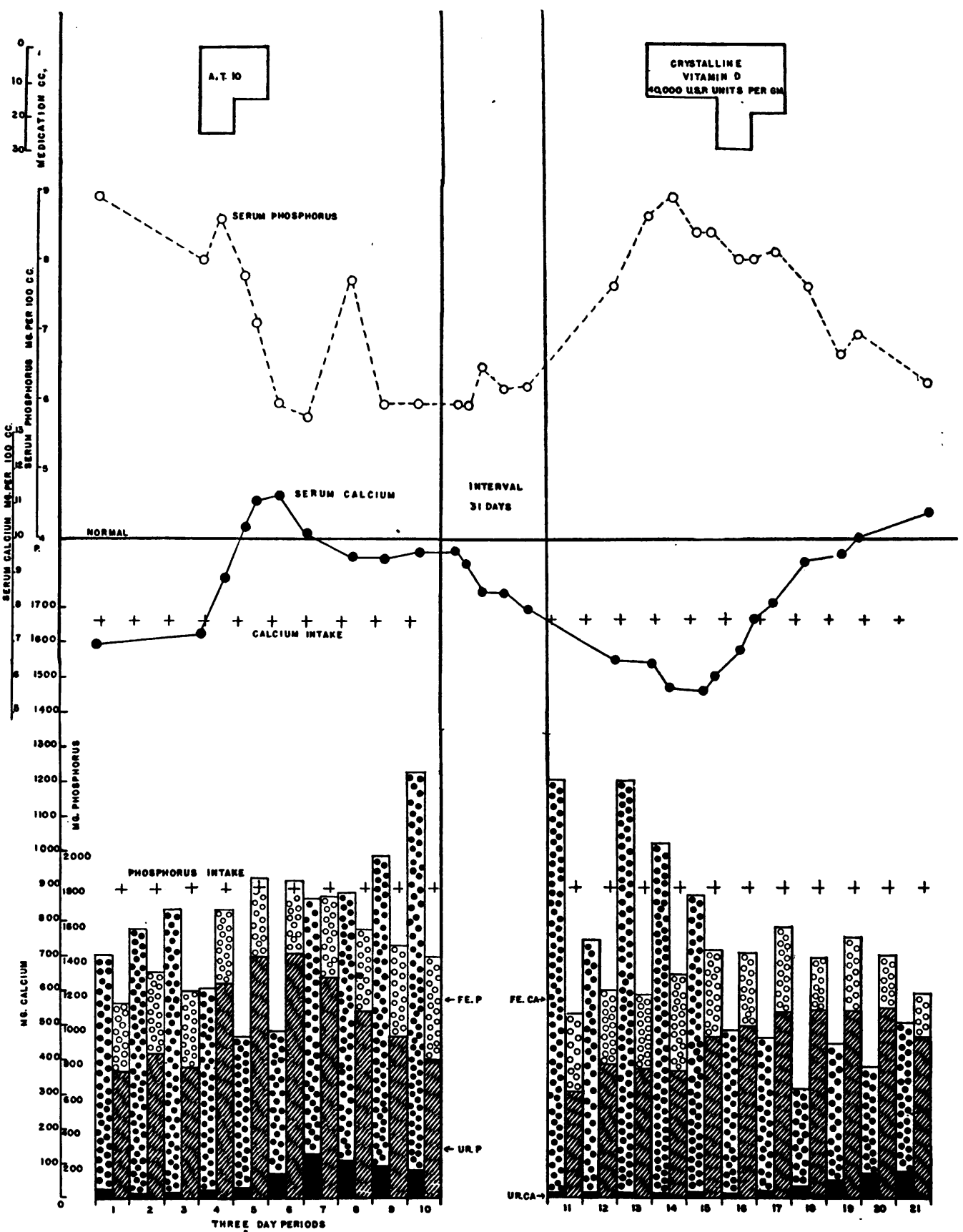

Fig. 1. Graphic Representation of Metabolic Date of Experiment I

phorus level (9.0 mgm. per $100 \mathrm{cc}$ ), the expected low urinary calcium excretion and a positive balance of both calcium and phosphorus.

With the administration of A.T. 10 (Periods 4 and 5), there was an immediate decrease in the fecal calcium excretion but no change in the fecal phosphorus excretion. The urinary phosphorus excretion, however, immediately rose, while the urinary calcium excretion remained unchanged. The positive calcium balance was, therefore, increased while the phosphorus balance was decreased and even became negative. The serum calcium level was elevated and the serum phosphorus level was depressed. With discontinuance 
of the drug in Period 6, these effects continued unabated for that period only; in Period 7 the fecal calcium excretion again began to rise and the urinary phosphorus excretion began to fall. The urinary calcium excretion did rise after the serum calcium level became normal and for some reason reached its highest level when the serum calcium was already falling. the experiment. With the administration of vitamin $D$ the fecal calcium excretion again decreases without any immediate change in the fecal phosphorus excretion; the urinary phosphorus excretion again rises without any immediate effect on the urinary calcium excretion. The serum calcium level eventually rises and the serum phosphorus value eventually falls. Finally the urin-

TABLE IA

Experiment I, Part A

\begin{tabular}{|c|c|c|c|c|c|c|c|c|c|c|c|c|c|}
\hline \multirow{2}{*}{$\begin{array}{c}\text { Three- } \\
\text { day } \\
\text { period }\end{array}$} & \multirow{2}{*}{ Date } & \multicolumn{4}{|c|}{ Calcium } & \multicolumn{4}{|c|}{ Phosphorus } & \multicolumn{3}{|c|}{ Serum } & \multirow{2}{*}{ Therapy } \\
\hline & & Urine & Feces & $\begin{array}{c}\text { In- } \\
\text { take }\end{array}$ & $\begin{array}{l}\text { Bal- } \\
\text { ance }\end{array}$ & Urine & Feces & $\begin{array}{l}\text { In- } \\
\text { take }\end{array}$ & $\begin{array}{l}\text { Bal- } \\
\text { ance }\end{array}$ & Calcium & $\begin{array}{l}\text { Phos- } \\
\text { phorus }\end{array}$ & $\begin{array}{l}\text { Phos- } \\
\text { phatase }\end{array}$ & \\
\hline 1 & $\begin{array}{c}\text { October } 1936 \\
8-9-10\end{array}$ & $\begin{array}{l}\text { grams } \\
0.03\end{array}$ & $\begin{array}{l}\text { grams } \\
0.68\end{array}$ & $\begin{array}{l}\text { grams } \\
1.67\end{array}$ & $\begin{array}{r}\text { grams } \\
+0.96\end{array}$ & $\begin{array}{l}\text { grams } \\
0.73\end{array}$ & $\begin{array}{l}\text { grams } \\
0.40\end{array}$ & $\begin{array}{l}\text { grams } \\
1.78\end{array}$ & $\begin{array}{l}\text { grams } \\
+0.65\end{array}$ & $\begin{array}{l}\text { mgm. per } \\
100 \mathrm{cc} \text {. } \\
7.0(\mathrm{I})^{*}\end{array}$ & $\begin{array}{c}\text { mgm. per } \\
100 \text { cc. } \\
9.0\end{array}$ & $\begin{array}{c}\underset{\text { units }}{\text { Bodansky }} \\
7.0\end{array}$ & \\
\hline 2 & $11-12-13$ & 0.02 & 0.76 & 1.67 & +0.89 & 0.83 & 0.47 & 1.78 & +0.48 & & & & \\
\hline 3 & $14-15-16$ & 0.02 & 0.81 & 1.67 & +0.84 & 0.75 & 0.45 & 1.78 & +0.58 & & & & \\
\hline 4 & $17-18-19$ & 0.03 & 0.58 & 1.67 & +1.06 & 1.24 & 0.43 & 1.78 & +0.11 & $\begin{array}{l}7.2(\mathrm{I}) \\
8.9(\mathrm{III})\end{array}$ & $\begin{array}{l}8.0 \\
8.6\end{array}$ & 5.6 & $\begin{array}{r}10 \text { cc. A.T. } 10 \\
10 \text { cc. A.T. } 10 \\
5 \text { cc. A.T. } 10\end{array}$ \\
\hline 5 & $20-21-22$ & 0.03 & 0.43 & 1.67 & +1.21 & 1.39 & 0.45 & 1.78 & -0.06 & $\begin{array}{l}10.4(\text { III) } \\
11.1 \text { (III) }\end{array}$ & $\begin{array}{l}7.8 \\
7.1\end{array}$ & 6.1 & $\begin{array}{l}5 \text { cc. A.T. } 10 \\
5 \text { cc. А.T. } 10 \\
5 \text { cc. А.T. } 10\end{array}$ \\
\hline 6 & $23-24-25$ & 0.07 & 0.41 & 1.67 & +1.19 & 1.41 & 0.42 & 1.78 & -0.05 & $11.2(\mathrm{II})$ & 5.9 & 4.1 & \\
\hline 7 & $26-27-28$ & 0.13 & 0.74 & 1.67 & +0.80 & 1.27 & 0.47 & 1.78 & +0.05 & $10.2(\mathrm{I})$ & 5.7 & 4.3 & \\
\hline 8 & $29-30-31$ & 0.11 & 0.77 & 1.67 & +0.79 & 1.07 & 0.47 & 1.78 & +0.24 & $9.5(\mathrm{II})$ & 7.7 & 2.6 & \\
\hline 9 & $\begin{array}{c}\text { November } \\
1-2-3\end{array}$ & 0.10 . & 0.89 & 1.67 & +0.68 & 0.92 & 0.52 & 1.78 & +0.34 & $9.5(\mathrm{II})$ & 5.9 & 4.5 & \\
\hline 10 & $4-5-6$ & 0.08 & 1.14 & 1.67 & +0.45 & 0.80 & 0.59 & 1.78 & +0.39 & $9.7(\mathrm{II})$ & 5.9 & & \\
\hline
\end{tabular}

* Roman numerals indicate to which day of period data refer.

From this experiment alone one would suspect that there are two primary metabolic effects of A.T. 10 (decrease of fecal calcium and increase of urinary phosphorus); that each of these lead to a secondary effect (rise in serum calcium and fall in serum phosphorus); and finally that one of these secondary effects (rise in serum calcium) in turn leads to a tertiary effect (increase in urinary calcium excretion).

When one turns to the second part of the experiment (Table IB), one finds the fecal calcium values in the control periods (Periods 11, 12, and 13) considerably higher than those in similar periods (Periods 1,2 , and 3 ) in the first half of ary calcium excretion rises. There is also a delayed fall in the fecal phosphorus excretion, suggesting that eventually the body compensates for the increased urinary phosphate excretion by an increased absorption of phosphorus.

It will be noted that all the changes were in the same direction as when A.T. 10 was administered. $^{3}$ There were, however, certain quantitative differences. The effect of vitamin $D$ in the

8 This statement is not quite true as there was no delayed decrease of fecal phosphorus excretion when A.T. 10 was administered. If one judges from later experiments, however (Tables IIA and III), this was because A.T. 10 was not administered for a sufficiently long time. 
doses used was slower in coming on; on the other hand, the effect, once there, remained longer after discontinuance of treatment. Secondly, if one confines ones attention to the two primary effects (to decrease the fecal calcium and to increase the urinary phosphorus), it will be noted that vitamin $D$ in the doses used effected fecal calcium as ef- that of A.T. 10, whereas the effect of vitamin D on the urinary phosphorus excretion was decidedly less than that of A.T. 10.

\section{Experiment II}

The subject, D. B., Number 8568 , of the second investigation, was a girl of 21 with severe

TABLE IB

Experiment $I$, Part $B$

\begin{tabular}{|c|c|c|c|c|c|c|c|c|c|c|c|c|c|}
\hline \multirow{2}{*}{$\begin{array}{c}\text { Three- } \\
\text { day } \\
\text { period }\end{array}$} & \multirow{2}{*}{ Date } & \multicolumn{4}{|c|}{ Calcium } & \multicolumn{4}{|c|}{ Phosphorus } & \multicolumn{3}{|c|}{ Serum } & \multirow{2}{*}{ Therapy } \\
\hline & & Urine & Feces & $\begin{array}{c}\text { In- } \\
\text { take }\end{array}$ & $\begin{array}{l}\text { Bal- } \\
\text { ance }\end{array}$ & Urine & Feces & In- & $\begin{array}{l}\text { Bal- } \\
\text { ance }\end{array}$ & Calcium & $\begin{array}{l}\text { Phos- } \\
\text { phorus }\end{array}$ & $\begin{array}{l}\text { Phos- } \\
\text { phatase }\end{array}$ & \\
\hline 11 & $\begin{array}{c}\text { December } 1936 \\
8-9-10\end{array}$ & $\begin{array}{l}\text { grams } \\
0.02\end{array}$ & $\begin{array}{l}\text { grams } \\
1.19\end{array}$ & $\begin{array}{l}\text { grams } \\
1.67\end{array}$ & $\begin{array}{l}\text { grams } \\
+0.46\end{array}$ & $\begin{array}{l}\text { grams } \\
0.60\end{array}$ & $\begin{array}{l}\text { grams } \\
0.54\end{array}$ & $\begin{array}{l}\text { grams } \\
1.78\end{array}$ & $\begin{array}{l}\text { grams } \\
+0.64\end{array}$ & $\begin{array}{l}\text { mgm. per } \\
100 \text { cc. }\end{array}$ & $\begin{array}{l}\text { mgm. per } \\
100 \text { cc. }\end{array}$ & $\begin{array}{l}\text { Bodansky } \\
\text { units }\end{array}$ & $\begin{array}{l}\text { Vitamin } D- \\
\text { U.S.P. }{ }^{2} \text { units }\end{array}$ \\
\hline 12 & $11-12-13$ & 0.02 & 0.73 & 1.67 & +0.92 & 0.76 & 0.43 & 1.78 & +0.59 & & & & \\
\hline 13 & $14-15-16$ & 0.02 & 1.18 & 1.67 & +0.47 & 0.74 & 0.43 & 1.78 & +0.61 & $6.5(I)^{*}$ & 7.6 & & \\
\hline 14 & $17-18-19$ & 0.01 & 1.01 & 1.67 & +0.65 & 0.73 & 0.56 & 1.78 & +0.49 & $\begin{array}{l}6.4(\text { I) } \\
5.7(\text { II) }\end{array}$ & $\begin{array}{l}8.7 \\
8.9\end{array}$ & & $\begin{array}{l}200,000 \\
200,000 \\
200,000\end{array}$ \\
\hline 15 & $20-21-22$ & 0.02 & 0.85 & 1.67 & +0.80 & 0.92 & 0.50 & 1.78 & +0.36 & $\begin{array}{l}5.6(\text { II }) \\
6.0 \text { (III) }\end{array}$ & $\begin{array}{l}8.4 \\
8.4\end{array}$ & 9.0 & $\begin{array}{l}200,000 \\
200,000 \\
200,000\end{array}$ \\
\hline 16 & $23-24-25$ & 0.02 & 0.47 & 1.67 & +1.18 & 0.99 & 0.42 & 1.78 & +0.37 & $6.8(\mathrm{II})$ & 8.0 & 7.5 & $\begin{array}{l}400,000 \\
400,000 \\
400,000\end{array}$ \\
\hline 17 & $26-27-28$ & 0.02 & 0.44 & 1.67 & +1.21 & 1.06 & 0.50 & 1.78 & +0.22 & $\begin{array}{l}7.6(\text { I) } \\
8.1(\text { II })\end{array}$ & $\begin{array}{l}8.0 \\
8.1\end{array}$ & $\begin{array}{l}7.2 \\
7.9\end{array}$ & $\begin{array}{l}400,000 \\
400,000\end{array}$ \\
\hline 18 & $29-30-31$ & 0.04 & 0.28 & 1.67 & +1.35 & 1.08 & 0.30 & 1.78 & +0.40 & $9.3(\mathrm{II})$ & 7.6 & 7.5 & \\
\hline 19 & $\underset{1-2-3}{\text { January }} 1937$ & 0.05 & 0.39 & 1.67 & +1.23 & 1.07 & 0.43 & 1.78 & +0.28 & 9.5 (II) & 6.6 & 6.1 & \\
\hline 20 & $4-5-6$ & 0.07 & 0.30 & 1.67 & +1.30 & 1.08 & 0.32 & 1.78 & +0.38 & $10.1(\mathrm{I})$ & 6.9 & & \\
\hline 21 & $7-8-9$ & 0.08 & 0.43 & 1.67 & +1.16 & 0.91 & 0.27 & 1.78 & +0.60 & 11.7 (III) & 6.2 & & \\
\hline
\end{tabular}

- Roman numerals indicate to which day of period data refer.

fectively as A.T. 10 if not more so. On the other hand, the action on the phosphorus excretion in the urine was less marked with vitamin $D$ than with A.T. 10.

The observations in the second part of this experiment could be summarized, therefore, by saying that the primary, secondary, and tertiary effects of vitamin $D$ were qualitatively the same as those of A.T. 10. However, the effect of vitamin $\mathrm{D}$ was slower in coming on and lasted longer. Finally, the effect of vitamin D on the fecal calcium excretion was as great if not greater than idiopathic hypoparathyroidism. A detailed clinical history will appear elsewhere (42).

Since in Experiment $I$ it had been shown that A.T. 10 could raise the serum calcium value by decreasing the fecal calcium excretion, it seemed of interest to try to determine whether the serum calcium could be raised on a low calcium intake. In other words, was A.T. 10 only effecting calcium absorption or could it prevent calcium excretion into the gut or even mobilize skeletal calcium? Unfortunately, because of the patient's severe degree of tetany it was impossible to carry 


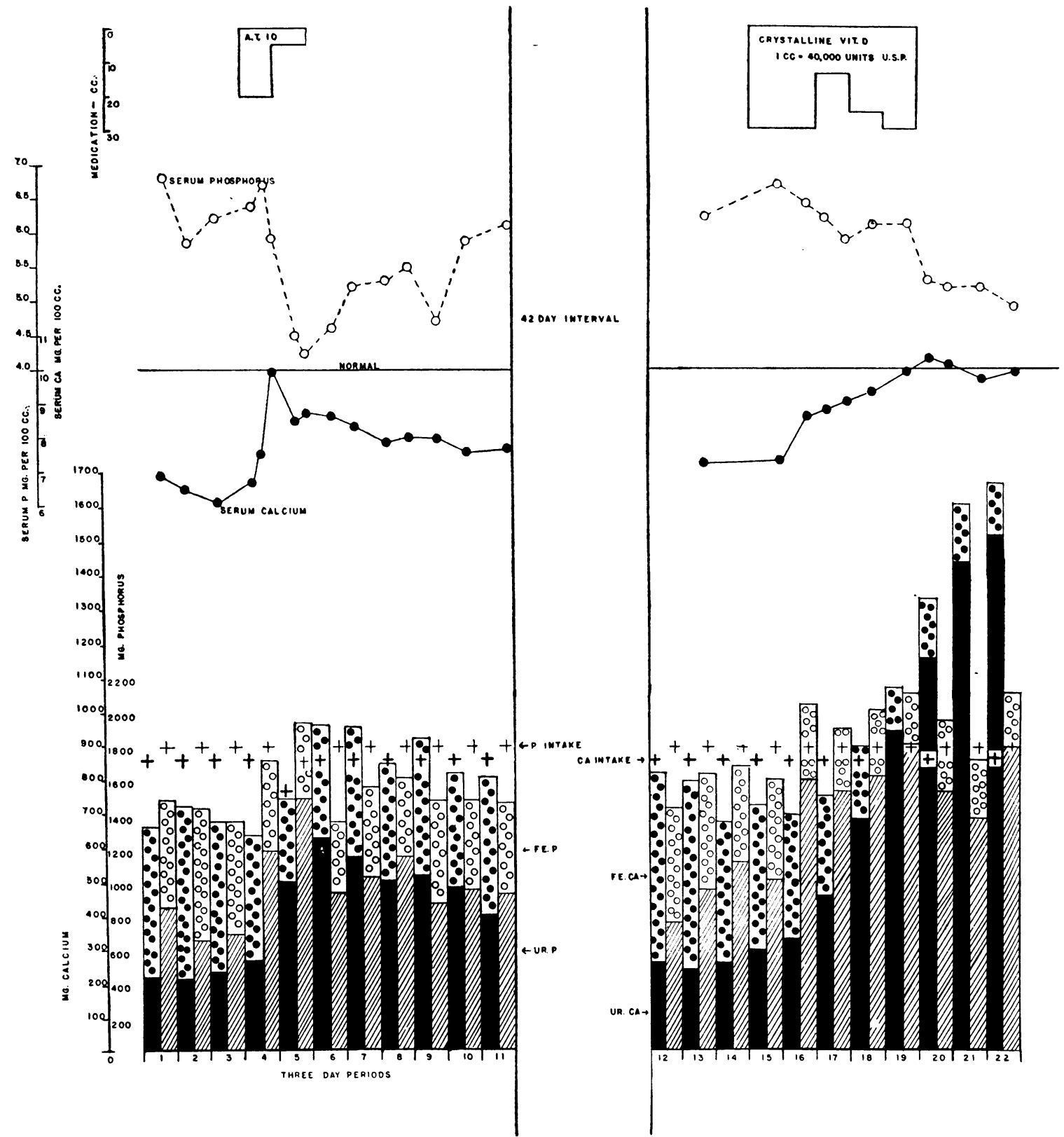

Fig. 2. Graphic Representation of Metabolic Data of Experiment II

her for control periods on a low calcium diet without added medication. Therefore, it was decided to put her on a low calcium diet ( 0.10 gram per day) and to give her intravenously, in addition, calcium gluconate ( 0.18 gram of calcium per day) in two divided doses. All blood samples were taken at least twelve hours after the previous intravenous calcium administration.

The experiment was divided into Parts $\mathrm{A}$ and
B. During Part A she received A.T. 10 and during Part $\mathrm{B}$ she received crystalline vitamin $\mathrm{D}$. The diet was of an exactly similar composition throughout. Sufficient time was allowed to elapse between Parts A and B to let the equilibria return to the premedication levels. The data are shown in Figure 2 and Tables IIA and IIB.

During the first three control periods, 1, 2, and 3 , she had much more calcium in her urine 
than she would have had with a serum calcium value of $6.9 \mathrm{mgm}$., had she not been receiving intravenous calcium medication. The excess (about $180 \mathrm{mgm}$.) undoubtedly resulted from the calcium given intravenously. It is of further interest that slightly more calcium was excreted in fecal phosphorus excretion, although not nearly large enough to account for the increased urinary phosphorus excretion.

There was a rise in urinary calcium excretion greater than the fall in fecal calcium excretion so that the calcium balance was decreased and even

TABLE IIA

Experiment II, Part A

\begin{tabular}{|c|c|c|c|c|c|c|c|c|c|c|c|c|}
\hline \multirow{2}{*}{$\begin{array}{l}\text { Three- } \\
\text { day } \\
\text { period }\end{array}$} & \multirow{2}{*}{ Date } & \multicolumn{4}{|c|}{ Calcium } & \multicolumn{4}{|c|}{ Phosphorus } & \multicolumn{2}{|c|}{ Serum } & \multirow{2}{*}{ Therapy } \\
\hline & & Urine & Feces & Intake & Balance & Urine & Feces & Intake & Balance & Calcium & Phosphorus & \\
\hline 1 & $\begin{array}{c}\text { February } 1937 \\
2-3-4\end{array}$ & $\begin{array}{l}\text { grams } \\
0.21\end{array}$ & $\begin{array}{l}\text { grams } \\
0.45\end{array}$ & $\begin{array}{l}\text { grams } \\
0.85^{*}\end{array}$ & $\begin{array}{l}\text { grams } \\
+0.19\end{array}$ & $\begin{array}{l}\text { grams } \\
0.85\end{array}$ & $\begin{array}{l}\text { grams } \\
0.61\end{array}$ & $\begin{array}{l}\text { grams } \\
1.78\end{array}$ & $\begin{array}{l}\text { grams } \\
+0.32\end{array}$ & 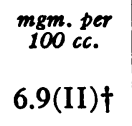 & 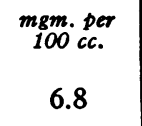 & \\
\hline 2 & $5-6-7$ & 0.21 & 0.51 & 0.85 & +0.13 & 0.65 & 0.77 & 1.78 & +0.36 & $6.5(I)$ & 5.8 & \\
\hline 3 & $8-9-10$ & 0.23 & 0.44 & 0.85 & +0.18 & 0.69 & 0.66 & 1.78 & +0.43 & $6.1(\mathrm{I})$ & 6.2 & \\
\hline 4 & $11-12-13$ & 0.27 & 0.37 & 0.85 & +0.21 & 1.18 & 0.53 & 1.78 & +0.07 & $\begin{array}{l}6.7(\mathrm{I}) \\
7.5(\mathrm{II}) \\
9.9(\mathrm{III})\end{array}$ & $\begin{array}{l}6.4 \\
6.7 \\
5.9\end{array}$ & $\begin{array}{r}10 \text { cc. A.T. } 10 \\
5 \text { cc. A.T. } 10 \\
5 \text { cc. A.T. } 10\end{array}$ \\
\hline 5 & $14-15-16$ & 0.50 & 0.24 & 0.76 & +0.02 & 1.48 & 0.44 & 1.78 & -0.14 & $\begin{array}{l}8.5 \text { (II) } \\
8.7(\text { III) }\end{array}$ & $\begin{array}{l}4.5 \\
4.3\end{array}$ & 5 cc. A.T. 10 \\
\hline 6 & $17-18-19$ & 0.63 & 0.33 & 0.85 & -0.11 & 0.93 & 0.42 & 1.78 & +0.43 & $8.6(\mathrm{II})$ & 4.6 & \\
\hline 7 & $20-21-22$ & 0.57 & 0.37 & 0.85 & -0.09 & 1.02 & 0.52 & 1.78 & +0.24 & $8.3(\mathrm{I})$ & 5.2 & \\
\hline 8 & $23-24-25$ & 0.50 & 0.34 & 0.85 & +0.01 & 1.14 & 0.46 & 1.78 & +0.18 & $\begin{array}{l}7.9(\mathrm{I}) \\
8.0(\mathrm{III})\end{array}$ & $\begin{array}{l}5.3 \\
5.5\end{array}$ & \\
\hline 9 & $26-27-28$ & 0.52 & 0.40 & 0.85 & -0.07 & 0.88 & 0.59 & 1.78 & +0.31 & $8.0(\mathrm{II})$ & 4.7 & \\
\hline 10 & $\begin{array}{c}\text { March } \\
1-2-3\end{array}$ & 0.48 & 0.33 & 0.85 & +0.04 & 0.95 & 0.52 & 1.78 & +0.31 & 7.6(II) & 5.9 & \\
\hline 11 & $4-5-6$ & 0.40 & 0.40 & 0.85 & +0.05 & 0.93 & 0.52 & 1.78 & +0.33 & 7.7 (III) & 6.1 & \\
\hline
\end{tabular}

* Patient received $10 \mathrm{cc}$. of 10 per cent calcium gluconate intravenously twice daily throughout the entire experiment except for Period 5, during which one injection was omitted. Therefore, the ingested calcium was 0.31 gram and the ingested calcium 0.54 gram.

$\dagger$ Roman numerals indicate to which day of period data refer.

the feces than was given by mouth. This confirms the work of Nicolayson (43) that the fecal calcium does not merely represent unabsorbed calcium in the diet.

During the periods of A.T. 10 administration (Periods 4 and 5) the fecal calcium excretion was decreased as in the previous experiment but not by more than the calcium in the diet.

Again, as in Experiment I, A.T. 10 had a very marked effect (about 100 per cent) on the urinary phosphorus excretion with the production of a negative phosphorus balance. In this experiment, however, there was a slight decrease in the became negative during Periods 6 and 7. This demonstrates that calcium can be mobilized from the skeleton with A.T. 10.

In Part B it is seen that again the effect of vitamin D was qualitatively the same as that of A.T. 10. The data again suggest that the action of vitamin $\mathrm{D}$ is slower and lasts longer. On the whole, it seems fair to conclude also that the ratio of the action of A.T. 10 on the urinary phosphorus excretion to that of its action on calcium absorption was greater with A.T. 10 than with vitamin $D$. In comparing Parts $A$ and $B$ in this respect, allowance must be made for the fact that 
TABLE IIB

Experiment $I I$, Part $B$

\begin{tabular}{|c|c|c|c|c|c|c|c|c|c|c|c|c|}
\hline \multirow{2}{*}{$\begin{array}{l}\text { Three- } \\
\text { day } \\
\text { period }\end{array}$} & \multirow{2}{*}{ Date } & \multicolumn{4}{|c|}{ Calcium } & \multicolumn{4}{|c|}{ Phosphorus } & \multicolumn{2}{|c|}{ Serum } & \multirow{2}{*}{ Therapy } \\
\hline & & Urine & Feces & Intake & Balance & Urine & Feces & Intake & Balance & Calcium & Phosphorus & \\
\hline 12 & $\begin{array}{c}\text { April } 1937 \\
18-19-20\end{array}$ & $\begin{array}{l}\text { grams } \\
0.26\end{array}$ & $\begin{array}{l}\text { grams } \\
0.55\end{array}$ & $\begin{array}{l}\text { grams } \\
0.85\end{array}$ & $\begin{array}{l}\text { grams } \\
+0.04\end{array}$ & $\begin{array}{l}\text { grams } \\
0.75\end{array}$ & $\begin{array}{l}\text { grams } \\
0.67\end{array}$ & $\begin{array}{l}\text { grams } \\
1.78\end{array}$ & $\begin{array}{l}\text { srams } \\
+0.36\end{array}$ & $\begin{array}{l}\text { mgm. per } \\
100 \text { cc. }\end{array}$ & $\begin{array}{l}\text { mgm. per } \\
100 \text { cc. }\end{array}$ & $\begin{array}{l}\text { Vitamin } D- \\
\text { U.S.P. units }\end{array}$ \\
\hline 13 & $21-22-23$ & 0.24 & 0.56 & 0.85 & +0.05 & 0.95 & 0.67 & 1.78 & +0.16 & $7.2(\mathrm{II})^{*}$ & 6.2 & \\
\hline 14 & $24-25-26$ & 0.26 & 0.42 & 0.85 & +0.17 & 1.12 & 0.56 & 1.78 & +0.10 & & & \\
\hline 15 & $27-28-29$ & 0.30 & 0.42 & 0.85 & +0.13 & 1.01 & 0.58 & 1.78 & +0.19 & 7.3(III) & 6.7 & $\begin{array}{l}400,000 \\
400,000 \\
400,000\end{array}$ \\
\hline 16 & $\underset{30-1-2}{\text { May }}$ & 0.33 & 0.36 & 0.85 & +0.16 & 1.59 & 0.45 & 1.78 & -0.26 & $8.6(\mathrm{II})$ & 6.4 & $\begin{array}{l}400,000 \\
400,000 \\
400,000\end{array}$ \\
\hline 17 & $3-4-5$ & 0.46 & 0.29 & 0.85 & +0.10 & 1.52 & 0.37 & 1.78 & -0.11 & $\begin{array}{l}8.8(\text { I) } \\
9.0(\text { III })\end{array}$ & $\begin{array}{l}6.2 \\
5.9\end{array}$ & $\begin{array}{l}400,000 \\
160,000\end{array}$ \\
\hline 18 & $6-7-8$ & 0.68 & 0.21 & 0.85 &.-0.04 & 1.62 & 0.39 & 1.78 & -0.23 & 9.3(II) & 6.1 & $\begin{array}{l}200,000 \\
400,000 \\
400,000\end{array}$ \\
\hline 19 & $9-10-11$ & 0.94 & 0.13 & 0.85 & -0.22 & 1.80 & 0.31 & 1.78 & -0.33 & 9.9 (II) & 6.1 & $\begin{array}{l}400,000 \\
400,000 \\
400,000\end{array}$ \\
\hline 20 & $12-13-14$ & 1.16 & 0.18 & 0.85 & -0.49 & 1.52 & 0.42 & 1.78 & -0.16 & $\begin{array}{l}10.3 \text { (I) } \\
10.1 \text { (III) }\end{array}$ & $\begin{array}{l}5.3 \\
5.2\end{array}$ & \\
\hline 21 & $15-16-17$ & 1.44 & 0.17 & 0.85 & -0.76 & 1.37 & 0.34 & 1.78 & +0.07 & 9.7 (III) & 5.2 & \\
\hline 22 & $18-19-20$ & 1.52 & 0.15 & 0.85 & -0.82 & 1.78 & 0.34 & 1.78 & -0.34 & 9.9(III) & 4.9 & \\
\hline
\end{tabular}

* Roman numerals indicate to which day of period data refer.

TABLE III

Metabolic data on Experiment III

\begin{tabular}{|c|c|c|c|c|c|c|c|c|c|c|c|c|}
\hline \multirow{2}{*}{$\begin{array}{l}\text { Three- } \\
\text { day } \\
\text { period }\end{array}$} & \multirow{2}{*}{ Date } & \multicolumn{4}{|c|}{ Calcium } & \multicolumn{4}{|c|}{ Phosphorus } & \multicolumn{2}{|c|}{ Serum } & \multirow{2}{*}{ Therapy } \\
\hline & & Urine & Feces & Intake & Balance & Urine & Feces & Intake & Balance & Calcium & Phosphorus & \\
\hline 1 & $\begin{array}{c}\text { May } 1937 \\
29-30-31\end{array}$ & $\begin{array}{l}\text { grams } \\
0.08\end{array}$ & $\begin{array}{l}\text { grams } \\
0.82\end{array}$ & $\begin{array}{l}\text { grams } \\
1.67\end{array}$ & $\begin{array}{l}\text { grams } \\
+0.77\end{array}$ & $\begin{array}{l}\text { grams } \\
0.75\end{array}$ & $\begin{array}{l}\text { grams } \\
0.50\end{array}$ & $\begin{array}{c}\text { grams } \\
1.78\end{array}$ & $\begin{array}{l}\text { srams } \\
+0.53\end{array}$ & $\begin{array}{l}\text { mgm. per } \\
100 \text { cc. }\end{array}$ & $\begin{array}{l}\text { mgm. per } \\
100 \text { cc. }\end{array}$ & \\
\hline 2 & $\underset{1-2-3}{\text { June }}$ & 0.11 & 1.03 & 1.67 & +0.53 & 0.94 & 0.70 & 1.78 & +0.14 & & & \\
\hline 3 & $4-5-6$ & 0.08 & 1.20 & 1.67 & +0.39 & 1.55 & 0.57 & 1.78 & -0.34 & $5.7(\mathrm{I})^{*}$ & 8.6 & $\begin{array}{l}5 \text { cc. A.T. } 10 \\
5 \text { cc. A.T. } 10 \\
5 \text { cc. A.T. } 10\end{array}$ \\
\hline 4 & $7-8-9$ & 0.19 & 0.81 & 1.67 & +0.67 & 1.75 & 0.40 & 1.78 & -0.37 & $\begin{array}{l}7.1 \text { (I) } \\
7.9 \text { (III) }\end{array}$ & $\begin{array}{l}7.6 \\
6.3\end{array}$ & $\begin{array}{l}5 \text { cc. A.T. } 10 \\
5 \text { cc. A.T. } 10\end{array}$ \\
\hline 5 & $10-11-12$ & 0.33 & 0.77 & 1.67 & +0.57 & 1.18 & 0.35 & 1.78 & +0.26 & 8.1(II) & 6.1 & 1 cc. A.T. 10 \\
\hline
\end{tabular}

* Roman numerals indicate to which day of period data refer. 
vitamin $D$ therapy was pushed much further than that with A.T. 10. Furthermore, since there was very little calcium to absorb (cf. low calcium diet) there was a limit to the amount by which the drugs could decrease the fecal calcium excretion.
The patient received a diet exactly similar to that used in Experiment I. During the control periods (Periods 1 and 2) the expected findings were present although the urinary calcium excretion was slightly higher than one would expect.

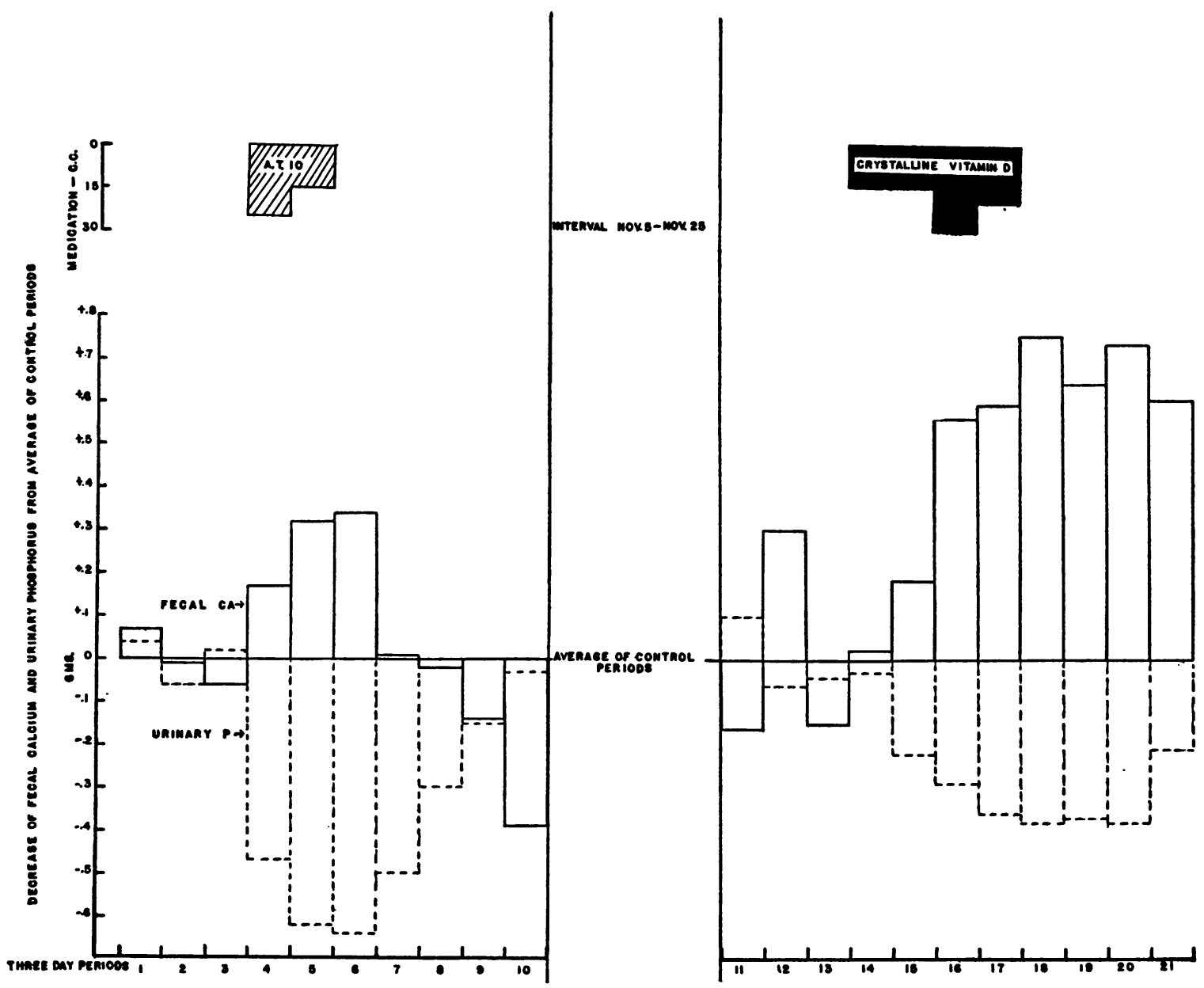

FIG. 3

This chart is constructed from data of Experiment I, Tables IA and IB. It is designed to show that the ratio of decrease in fecal $\mathrm{Ca}$ excretion to increase in urinary $\mathrm{P}$ excretion is greater with vitamin $\mathrm{D}$ than with A.T. 10. Base line represents average fecal $\mathrm{Ca}$ excretion and average urinary $\mathrm{P}$ excretion of control periods. The difference between the average values and the values for each period are plotted for each period-above the line if the difference represents a saving to the body, below the line if a loss. It will be noted that the $\mathrm{Ca}$ effect is greater with vitamin $D$, while the $P$ effect is greater with A.T. 10.

\section{Experiment III}

The subject, M. F. McC., Number 48512, of this experiment was a woman of 40 with severe postoperative hypoparathyroidism, for which she had been followed at the Massachusetts General Hospital since March, 1930. The thyroid operation had been performed at another hospital in June, 1929.
The blood values before medication were for the serum calcium 5.7 and for the serum phosphorus $8.6 \mathrm{mgm}$. per $100 \mathrm{cc}$. (Table III).

The patient received A.T. 10 during Periods 3, 4 , and 5. The most striking effect again was on the urinary phosphorus excretion, there being about a 100 per cent increase over the control periods during Period 4. The serum phosphorus 
TABLE IV

Data showing effect of parathyroid hormone in hypoparathyroidism

\begin{tabular}{|c|c|c|c|c|c|c|c|c|c|c|c|}
\hline \multirow{2}{*}{$\begin{array}{l}\text { Three- } \\
\text { day } \\
\text { period }\end{array}$} & \multicolumn{4}{|c|}{ Calcium } & \multicolumn{4}{|c|}{ Phosphorus } & \multicolumn{2}{|c|}{ Serum } & \multirow{2}{*}{ Therapy } \\
\hline & Urine & Feces & Intake & Balance & Urine & Feces & Intake & Balance & Calcium & Phosphorus & \\
\hline 20 & $\begin{array}{c}\text { grams } \\
0.12\end{array}$ & $\begin{array}{c}\text { grams } \\
2.60\end{array}$ & $\begin{array}{c}\text { grams } \\
3.85\end{array}$ & $\begin{array}{l}\text { grams } \\
+1.13\end{array}$ & $\begin{array}{c}\text { grams } \\
0.58\end{array}$ & $\begin{array}{l}\text { grams } \\
0.70\end{array}$ & $\begin{array}{c}\text { grams } \\
1.99\end{array}$ & $\begin{array}{l}\text { grams } \\
+0.71\end{array}$ & $\begin{array}{c}m g m \cdot \text { per } \\
100 \mathrm{cc} \\
8.9(\mathrm{I})^{*}\end{array}$ & $\begin{array}{c}m g m . \text { per } \\
100 \text { cc. } \\
6.9\end{array}$ & $\begin{array}{c}\text { parathormone- } \\
\text { units }\end{array}$ \\
\hline 21 & 0.11 & 2.40 & 3.85 & +1.34 & 0.54 & 0.65 & 1.99 & +0.80 & 8.9 (II) & 6.9 & \\
\hline 22 & 0.11 & 2.94 & 3.85 & +0.80 & 0.50 & 0.96 & 1.99 & +0.53 & $8.6(\mathrm{II})$ & 7.3 & \\
\hline 23 & 0.12 & 2.71 & 3.85 & +1.02 & 0.45 & 0.62 & 1.99 & +0.92 & $8.8(\mathrm{III})$ & 6.8 & \\
\hline 24 & 0.18 & 3.33 & 3.85 & +0.34 & 1.62 & 0.81 & 1.99 & -0.44 & $\begin{array}{c}8.3(\text { I }) \\
10.5(\text { II }) \\
11.0(\text { III) }\end{array}$ & $\begin{array}{l}7.3 \\
5.0 \\
5.0\end{array}$ & $\begin{array}{l}40 \\
40 \\
40\end{array}$ \\
\hline 25 & 0.27 & 2.24 & 3.85 & +1.34 & 0.97 & 0.77 & 1.99 & +0.25 & $10.2(\mathrm{II})$ & 5.4 & $\begin{array}{l}40 \\
40 \\
40\end{array}$ \\
\hline 26 & 0.33 & 2.47 & 3.85 & +1.05 & 1.13 & 0.49 & 1.99 & +0.37 & $\begin{array}{l}\text { 12.3(I) } \\
11.2(\mathrm{II})\end{array}$ & $\begin{array}{l}5.3 \\
4.7\end{array}$ & $\begin{array}{l}40 \\
60 \\
60\end{array}$ \\
\hline
\end{tabular}

* Roman numerals indicate to which day of period data refer.

** One unit of parathormone is equivalent to 5 units of parathyroid extract.

value fell from $8.6 \mathrm{mgm}$. to $6.1 \mathrm{mgm}$. There was a slight decrease in the fecal calcium excretion and a slight rise in the urinary calcium excretion. The net result was that the calcium balance was little affected while the phosphorus balance was made negative. These findings strengthen the observations made in the previous experiments.

\section{DISCUSSION}

In a previous paper (2) the tentative hypothesis was made that there are two fundamental actions of vitamin D-to increase calcium absorption and to increase urinary phosphorus excretion. A.T. 10 has both of these properties, but the ratio of the effect on phosphorus excretion to that on calcium absorption is apparently greater with A.T. 10 than with vitamin D (Figure 3). Since the calcium absorption effect is obviously an antirachitic one whereas the phosphate excretion effect would work in the opposite direction, some explanation is afforded as to why A.T. 10 is not antirachitic.

Since one of the main actions of A.T. 10 appears to be to increase the excretion of urinary phosphorus and since the theory has been advanced that this is the fundamental action of the parathyroid hormone (44) it becomes of interest to compare the metabolic action of A.T. 10 with that of the parathyroid hormone. A priori one would expect them to be the same except for the fact that A.T. 10 has an additional action in causing increased calcium absorption.

In Table IV, data are given on the effect of the parathyroid hormone on the calcium and phosphorus metabolism of the same individual with postoperative hypoparathyroidism studied in Experiment III. During the control periods ( $\mathrm{Pe}-$ riods $20,21,22$, and 23 ), the patient had a positive balance of both calcium and phosphorus; the serum calcium was $8.9 \mathrm{mgm}$. per $100 \mathrm{cc}$. and the serum phosphorus was $6.9 \mathrm{mgm}$. per $100 \mathrm{cc}$. Up to the onset of the experiment the patient had been receiving large amounts of vitamin $\mathrm{D}$ which explains why the serum calcium was as high as it was (Table III).

With administration of parathormone in Period 24 there was the expected large increase in the urinary excretion of phosphorus with a lowering of the serum phosphorus. The fecal calcium ex- 
cretion was little, if at all, influenced, however. With a lowering of the serum phosphorus there was a rise in the serum calcium and an increased an additional action on calcium metabolism which the parathyroid hormone does not possess (Figure 4).
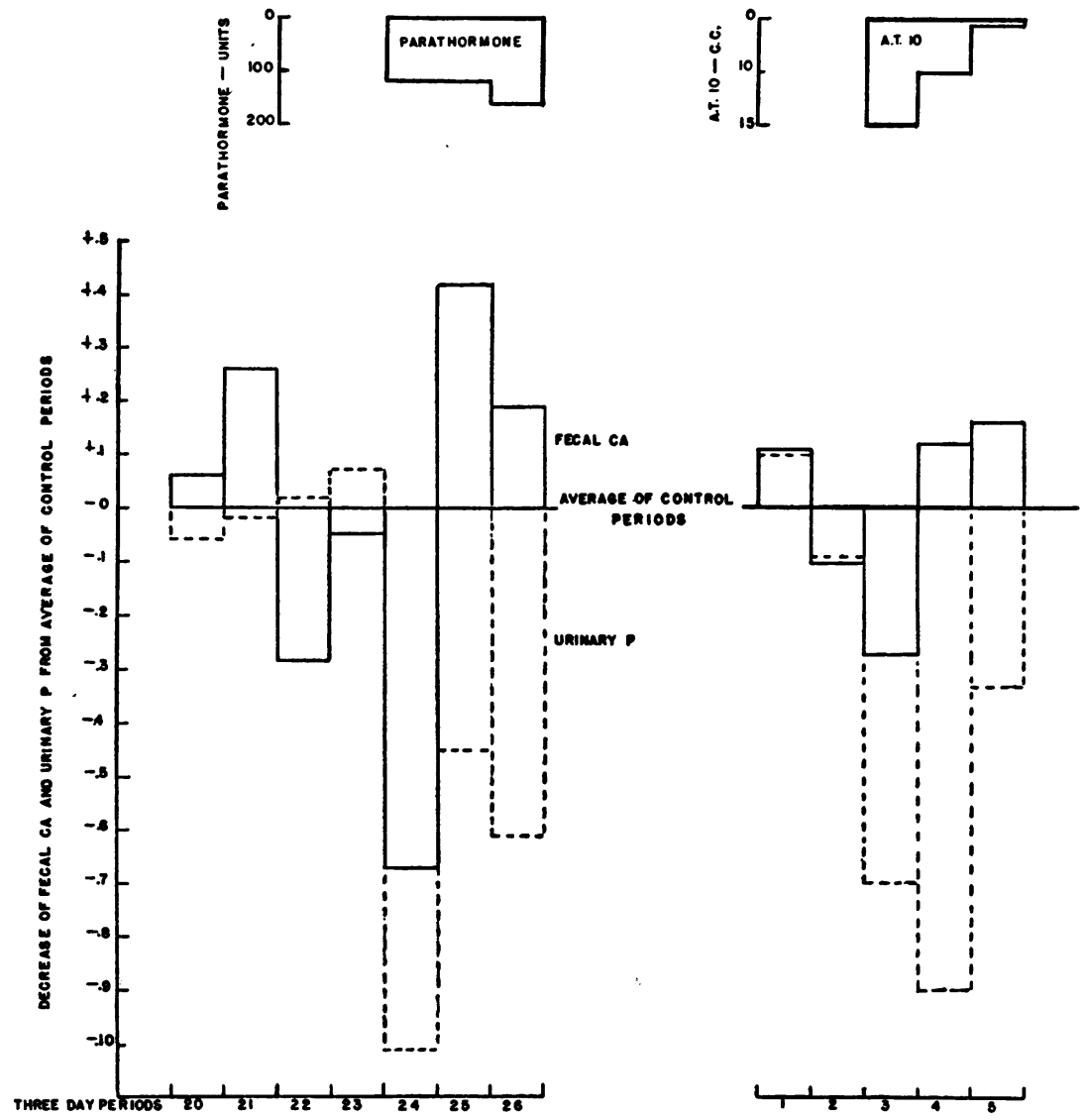

FIG. 4

This is constructed similarly to Figure 3 (q.v.). It is designed to show the difference between the effect of the parathyroid hormone on fecal $\mathrm{Ca}$ and urinary $P$ excretions and that of A.T. 10.

The chart is constructed from the data in Tables III and IV. It will be noted that both A.T. 10 and the parathyroid hormone have a similar effect on urinary $P$ excretion. The fecal calcium excretion in the parathormone experiment, however, showed no constant variations. The large fluctuations were to be expected because of the large $\mathrm{Ca}$ intake in that experiment. A.T. 10 on the other hand probably did have a definite effect on fecal calcium (although one would not be sure from this experiment above).

calcium excretion in the urine. The findings fit the hypothesis that the fundamental action of the parathyroid hormone on phosphorus metabolism is the same as that of A.T. 10 while A.T. 10 has
In a previous paper (2) the following diagram was presented to show the main actions of vitamin $\mathrm{D}$ on calcium and phosphorus metabolism and the sequelae of these actions : 


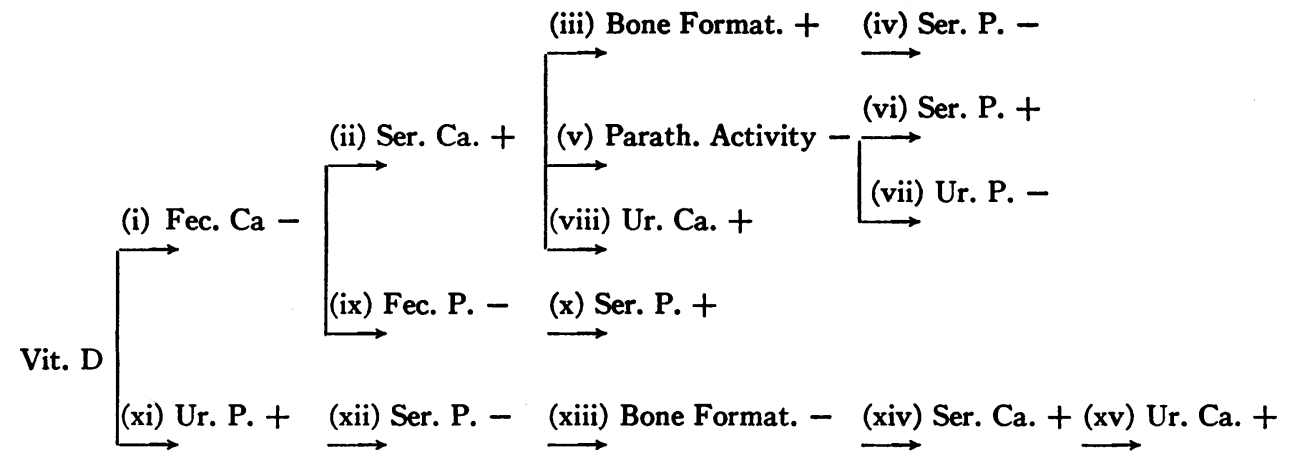

A similar diagram for A.T. 10 would be the same except that Arrow xi and its sequelae would be more accentuated. In a diagram for the parathyroid hormone Arrow xi would be accentuated, likewise, whereas Arrow $i$ and all its sequelae would be absent."

The studies here reported, therefore, suggest that the biological action of A.T. 10 differs from that of vitamin $\mathrm{D}$ in the direction of the parathyroid hormone. It would seem that if the difference could be somewhat further extended, one might actually synthesize a substance with the same biological properties as the parathyroid hormone, if not the hormone itself. If that were the case the parathyroid hormone would join that large group of hormones with chemical compositions resembling cholesterol.

\section{SUMMARY AND CONCLUSIONS}

1. The actions of A.T. 10 and of vitamin D on the calcium and phosphorus metabolism of three patients with hypoparathyroidism were studied; in one of the three patients the effect of the parathyroid hormone was likewise determined.

2. Both vitamin D and A.T. 10 had the same fundamental two actions-to increase calcium absorption from the gut and to increase phosphorus excretion in the urine; the ratio of the latter action to the former, however, was apparently greater with A.T. 10, which may explain why A.T. 10 is not antirachitic.

3. The action of vitamin D was slower in coming on and lasted longer than that of A.T. 10.

4. The parathyroid hormone resembled A.T.

\footnotetext{
4 These diagrams are presented, not that the authors have much hope that they will not have to be modified at a later date, but to help correlate a rather confusing mass of data.
}

10 as regards its property of causing a markedly increased urinary phosphorus excretion but differed in that it probably had no primary action on calcium absorption from the gut.

5. Because of the similarity between the actions of the parathyroid hormone and of A.T. 10, the latter drug is a most efficacious therapeutic agent in the treatment of hypoparathyroidism.

\section{BIBLIOGRAPHY}

1. Holtz, F., Die Behandlung der postoperativen Tetanie. Arch. f. klin. Chir. (Proc.), 1933, 177, 32.

2. Albright, F., and Sulkowitch, H. W., The effect of vitamin $\mathrm{D}$ on calcium and phosphorus metabolism; studies on four patients. J. Clin. Invest., 1938, 17, 305.

3. Bamberger, Ph., Zur Frage der Vigantolschäden. Deutsches med. Wchnschr., 1929, 55, 399.

4. von Wendt, G., Ist das D-Vitamin eine einheitliche Substanz? Klin. Wchnschr., 1930, 9, 166.

5. Windaus, A., Ergosterin und vitamin D. Forsch. u. Fortschr., 1930, 6, 209.

6. Holtz, F., Laquer, F., Kreitmair, H., and Moll, Th., Beiträge zur Kenntnis des Vitamins D. I. Die Wertbestimmung im Tierversuch. Biochem. Ztschr., 1931, 237, 247.

7. Holtz, F., Gissel, H., and Rossmann, E., Experimentelle und klinische Studien zur Behandlung der postoperativen Tetanie mit A.T. 10. Deutsche Ztschr. f. Chir., 1934, 242, 521.

8. Holtz, F., and Kramer, F., Uber Nebenschilddrüsentetanie, Kalkhaushalt, elektrische Erregbarkeit und A.T. 10. Naturwissenschaften, 1936, 24, 177.

9. Harnapp, G. O., Zur Pathogenese der Spasmophilie Behandlungsversuche mit A.T. 10. Monatschr. f. Kinderh., 1935, 63, 262.

10. Symposium: Die Tetanie (Nebenschilddrüseninsuffizienz) und ihre Behandlung. Med. Klin., 1936, $32,656$.

11. Roggenbau, C., Die Behandlung der postoperativen Tetanie. Arch. f. klin. Chir., 1933, 177, 34.

12. Rieder, W., Die Behandlung der postoperativen Tetanie. Arch. f. klin. Chir., 1933, 177, 35. 
13. Gissel, H., Die Behandlung der postoperativen Tetanie. Arch. f. klin. Chir., 1933, 177, 37.

14. Snapper, I., The treatment of tetany. Lancet, 1934, $1,728$.

15. Rieder, W., Neue Erfahrungen beim Vergleich verschiedener Methoden zur Behandlung der postoperativen Tetanie. München. med. Wchnschr., 1933, 80, 1207.

16. Martini, P., and Heymer, A., Beitrag zur behandlung der postoperativen Tetanie mit dem antitetanischen Präparat 10 (A.T. 10-Holtz). München. med. Wchnschr., 1933, 80, 1864.

17. Rieder, W., Klinische Erfahrungen mit A.T. 10. Zentralbl. f. Chir. (Proc.), 1934, 61, 2154.

18. Rieder, W., Klinische Erfahrungen mit A.T. 10. Zentralbl. f. Chir., 1934, 61, 2482.

19. Holtz, F., Wann ist eine Tetanie mit A.T. $10 \mathrm{zu}$ behandeln? Deutsche med. Wchnschr., 1934, 60, 1830.

20. Winterstein, O., Zur Behandlung schwerer und leichter Tetanien mit A.T. 10. Deutsche med. Wchnschr., 1934, 60, 1831.

21. Rieder, W., Erfahrungen mit A.T. 10. Deutsche med. Wchnschr., 1934, 60, 1832.

22. Wendt, H., and Altenburger, E., Zur Behandlung der postoperativen Tetanie mit A.T. 10 (Holtz). Med. Klin., 1934, 30, 765.

23. Eliot, T. R., Treatment of tetany. Lancet, 1935, 1, 641.

24. Ekblom, Tore, Zur Behandlung der postoperativen Tetanie mit A.T. 10. Acta chir. Scandinav., 1935, 77, 125.

25. Marzahn, Hans, Uber elektrokardiographische Veränderungen bei postoperativer Tetanie. Deutsche med. Wchnschr., 1935, 61, 507.

26. Arnold, C. H., and Blum, H., The control of hypoparathyroidism. West. J. Surg., 1936, 44, 546.

27. Halbertsma, J. J., A.T. 10 in therapy of parathyroid tetany. Nederl. tijdschr. v. geneesk., 1936, 80, 2844.

28. Holtz, F., Welche Störungen im Nerven und Kreislaufsystem lassen sich durch A.T. 10 beseitigen? Med. Welt., 1937, 11, 172.

29. Jelke, H., Ein mit A.T. 10 behandelter Fall von idiopathischer Tetanie, samt einer Uebersicht über die Tetanien mit besonderer Hinsicht auf Pathogenese und Therapie. Acta med. Scandinav., Supp., 1937, 81, 1.
30. Jordans, G. H. W., A new remedy against tetany. Nederl. tijdschr. v. geneesk., 1934, 78, 2750.

31. Feledy, K., Treatment of idiopathic tetany by means of A.T. 10. Orvosi Hetilap., 1936, 80, 612. Quoted from Chem. Absts., 1936, 30, 6825.

32. Arnold, O., Holtz, F., and Marx, H., Uber Beziehungen der Sexualhormone zum Kalkstoff wechsel und zum Knochenmark. Naturwissenschaften, 1936, 24, 314.

33. Rauh, W., Uber die Einwirkung des A.T. 10 auf die Linsen trübungen bei der experimentellen $\mathrm{Te}$ tanie der Ratten. Ber. ü. d. Versamml. d. deutsch. ophth. Gesellsch., 1936, 51, 357.

34. Gissel, H., Uber die Behandlung der Hämophilie mit A.T. 10. Zentralbl. f. Chir., 1934, 61, 2488.

35. Gissel, $H$., Uber die Behandlung der Hämophilie mit A.T. 10. Arch. f. klin. Chir., 1934, 180, 647.

36. Pfenninger, H., Zur Behandlung der Hämophilie mit A.T. 10. Deutsche Ztschr. f. Chir., 1935, 244, 242.

37. Danckelman, A., Erfahrungen zur Behandlung schmerzhafter Krampfadern und phlebitischer Reizzustände. Arch. f. klin. Chir., 1934, 180, 173.

38. Holtz, F., and Kramer, F., Wirkungsweise, Indikation und Gefahren von A.T. 10. Therap d. Gegenw., 1936, 77, 241 and 295.

39. Holtz, F., Die Nebenschilddrüseninsuffizienz, ihre Diagnose und Behandlung. Ber. ü. d. Versamml. d. deutsch. ophth. Gesellsch., 1936, 51, 354.

40. Hoff, F., Untersuchungen über die Wirkung des Präparates A.T. 10 bei parathyreopriver Tetanie. Arch. f. exper. Path. u. Pharmakol., 1935, 177, 204.

41. Holtz, F., Bericht über Erfahrungen mit A.T. 10 mitgeteilt in der Sitzung der Berliner Gesellschaft für Psychiatrie und Nervenkrankheiten am 12, Dezember, 1933. Klin. Wchnschr., 1934, 13, 104.

42. Drake, T. G., Albright, F., Bauer, W., and Castleman, B., Chronic idiopathic hypoparathyroidism. Report of seven cases with autopsy findings in one. (To be published.)

43. Nicolaysen, R., Studies upon the mode of action of vitamin D. II. The influence of vitamin $D$ on the fecal output of endogenous calcium and phosphorus in the rat. Biochem. J., 1937, 31, 107.

44. Albright, F., and Ellsworth, R., Studies on the physiology of the parathyroid glands. I. Calcium and phosphorus studies on a case of idiopathic hypoparathyroidism. J. Clin. Invest., 1929, 7, 183. 